\title{
INVENTORES E MESTRES: JOÃO VÁRIO E ARMÉNIO VIEIRA
}

\author{
INVENTORS AND MASTERS: \\ JOÃO VÁRIO AND ARMÉNIO VIEIRA
}

Rui Guilherme Silva*

\section{RESUMO}

João Vário e Arménio Vieira são hoje os poetas mais influentes de Cabo Verde. Nos primeiros anos após a Independência do país, Vário publica no jornal Voz di Povo alguns excertos das "Epístolas ao meu irmão António", nas quais exige a criação de uma poesia mais complexa, informada e universalista do que aquela que as novas gerações haviam herdado de Claridade. Concomitantemente, apela ao aparecimento em Cabo Verde de críticos literários "lúcidos, cultos, profissionais". Arménio Vieira, então coordenador das páginas de cultura de Voz di Povo, comenta as mais polémicas teses de Vário e analisa um excerto do futuro Exemplo Próprio. A invenção de Silvenius, alter-ego libertário de Vieira, cauciona a superação definitiva da estética de Claridade e o estabelecimento de um novo paradigma poético de cariz cosmopolita.

PALAVRAS-CHAVE: João Vário; Arménio Vieira; Crítica literária.

\section{ABSTRACT}

João Vário and Arménio Vieira are today's most influential Cape Verdean poets. During the first years after Independency Vário publishes in the weekly Voz di Povo some excerpts of the "Epistles to my brother António", in which he demands the creation of a more complex, knowledgeable and universal poetry than the one the new generations had inherited from $\mathrm{Cla}$ ridade. Concomitantly, he requests the appearance of "lucid, wise, professional" literary critics in Cape Verde. Arménio Vieira, who coordinated the cultural pages of Voz di Povo at the time, comments Vário's most controversial theses, and analyses an excerpt of the later Exemplo Próprio. The invention of Silvenius, the libertarian alter-ego of Vieira, endorses the final overcoming of Claridade's aesthetic and the establishment of a new poetic paradigm of cosmopolitan nature.

KEYWORDS: João Vário; Arménio Vieira; Literary criticism. 


\section{O “TEXTO 1" DE JOÃO VÁRIO}

Em abril do ano 2000, na secção "Arquivo Literário" da revista Anais, dirigida por João Manuel Varela, foi divulgada uma carta expedida por Jorge de Sena, desde o Brasil, e datada de 17 de junho de 1961. A missiva era dirigida a um "grupo de jovens poetas, entre os quais João Vário" (pseudónimo de J. M. Varela), e seguia acompanhada pelo então inédito "Camões dirige-se aos seus contemporâneos" (VARELA, 2000, p. 125). O autor de Fidelidade agradecia a oferta da revista $\hat{E} x o d o$, nesse ano publicada em Coimbra, e, em particular, o elogio que lhe dirigira o seu diretor, no “Texto 1", que abre a publicação. O signatário desta justa catilinária contra o ambiente literário português (na apreciação de Jorge de Sena) tinha 23 anos, era estudante de Medicina, e publicara em 1958 um livro de poemas intitulado Horas sem Carne, que logo retiraria do mercado. Esta rejeição decorria de uma alteração profunda nos interesses e nas exigências literárias do jovem autor cabo-verdiano: acontecida entre 1958 e 1961, ela viria a condicionar toda a sua obra poética, publicada nas quatro décadas seguintes.

É por dentro do sistema literário português, e enquanto poeta português, que João Vário problematiza a mudança que crê necessária, estabelecendo as suas normas programáticas e apresentando o "Canto Primeiro" do futuro Exemplo Geral (1966) ${ }^{2}$. A necessidade de acertar o passo com a Europa, muito insistente na sua crítica, insinua uma aspiração transnacional ou cosmopolita herdeira da ideia de Weltliteratur. Vário quer ver surgir uma poesia que não seja "apenas portuguesa" - e oferece um primeiro exemplo dessa poesia necessária. Ao contrário do que foi depois afirmado em diferentes lugares, este desejo de universalização não conduzirá, porém, a um estado de "poesia pura", tal como a entenderam Mallarmé ou Valéry. O registo autobiográfico de Exemplo Relativo (1968), o contexto histórico de Exemplo Precário (1981) ou a convergência de ambos em Exemplo Coevo (1998) garantem a presença quase constante de um cenário circunstancial nos palcos da reflexão lírica de Vário.

O “Texto 1" da revista Exxodo pode ser lido como o manifesto programático de um grupo de poetas residentes em Coimbra e do qual faziam parte, entre outros, Rui Mendes, Eduíno de Jesus e Luís Serrano. O primeiro deles escrevera uma recensão crítica sobre O Amor em Visita, publicada no número único do Jornal de Poesia, de 1958 (proibido pela censura, este jornal contara também com a direção de Vário). Três anos depois, na secção “Testemunho" da revista Êxodo, é o próprio Herberto Helder que publica o seu primeiro ensaio, intitulado “Ofício de Poeta”. Embora Vário não o declare explicitamente, quer o madeirense quer Ruy Belo, além de Jorge de Sena, são nomes fundamentais para o enquadramento geracional dos Exemplos ${ }^{3}$.

O programa poético proposto no "Texto 1" desenvolve-se a partir de duas interrogações complementares: "Que poesia se faz atualmente em Portugal?” e "Como fazer poesia que não seja apenas "poesia portuguesa»"? O diagnóstico de Vário percebe a permanência de "uma poesia 
menor, uma poesia de pequeníssima informação cultural" (VÁRIO, 1961, p. 1), devedora da importação superficial dos nomes mais divulgados do simbolismo e do surrealismo franceses, como Mallarmé, Verlaine, Éluard, Aragon e Prévert, além dos dois poetas da língua alemã traduzidos por Paulo Quintela, Hölderlin e Rilke. A perseverança do magistério de Régio e Torga - poetas "de antes de Pessoa", a quem era urgente regressar - testemunha a estagnação da lírica portuguesa contemporânea.

A ultrapassagem deste estádio exige o estudo e assimilação profunda da grande poesia universal árabe, hebraica (da Bíblia), egípcia (do Livro dos Mortos), grega (Homero), latina (Virgílio, Horácio), medieval (Dante) e renascentista (Shakespeare); e também dos grandes poetas da contemporaneidade ocidental, nomeadamente Eliot, Pound, Perse, Kavafis, Maiakovski, Quasimodo e García Lorca. Será ainda necessário ler a melhor prosa do século, nomeadamente Joyce, Proust e Kafka, bem como as filosofias da existência propostas por Kierkegaard, Husserl, Heidegger, Jaspers e Merleau-Ponty; enfim, seria urgente conhecer os ficcionistas que dela partem e a desenvolvem, como Sartre, Simone de Beauvoir, Camus ou Malraux. Ambas, filosofia e ficção contemporâneas, precisam de se comprometer com a fatura poética. Só trabalhando com a herança dos clássicos do passado e do presente se poderia superar as fronteiras da demasiado restrita nacionalidade poética ${ }^{4}$.

Este manifesto programático reproduz, naturalmente, alguns aspetos da discussão contemporânea em torno da poesia portuguesa. Os dados mais imediatos dirão respeito, em geral, ao desejo de sintonização com a poesia europeia ou ocidental e com a assimilação das filosofias da existência; bem como, em particular, à crescente valorização de Pessoa e à ultrapassagem da herança presencista. Haviam passado escassos meses desde a publicação, pela Nova Aguilar, da Obra Poética preparada por Maria Aliete Galhoz (e que Sena recebeu com as memórias dos seus "Vinte e cinco anos de Fernando Pessoa"). Entretanto, Eduardo Lourenço agitara as águas críticas ao publicar, no Comércio do Porto, o ensaio "Presença ou a contrarrevolução do modernismo" (1960), cuja tese, conforme assinalou Osvaldo Manuel Silvestre (2013, p. 291), surge secundada por Vário.

Os poetas portugueses que o cabo-verdiano considera acima da mediocridade geral denunciam a opção, confirmada na obra que há de produzir, por um discurso poético de configuração narrativa, de referências cultas e de expressão barroca. Oriundos das duas séries dos Cadernos de Poesia (que, aliás, publicarão Pessoa e Pascoaes, também citados por Vário), Tomás Kim, José Blanc de Portugal e Jorge de Sena representam a filiação anglófona, filosófica e por vezes religiosa das lições de T. S. Eliot e de Ezra Pound. Por sua vez, Fernando Echevarría e Pedro Tamen partilharão com o autor dos Exemplos certas maneiras de feição neobarroca, sujeitas a uma elaboração conceptual que não recusa a opacidade do hermetismo. $\mathrm{O}$ madeirense inscreve ainda nos interesses de Vário alguns recursos da poesia concreta: não os lúdicos, sonoros ou visuais (como em E. M. de Melo e 
Castro ou em Ana Hatherly), nem os do despojamento e da cesura frásica (como na Poesia 61), mas os das regras da composição, aliás estudadas por Ruy Belo, devedoras de certo "modelo da variação e do contraponto" (SILVESTRE, 2008, p. 636), conforme os poemas longos de T. S. Eliot, Saint-John Perse e, em particular, Herberto Helder.

É justamente por causa do interesse que demonstraram por Eliot e Pound que Vário se refere aos poetas dos Cadernos de Poesia, da Árvore, da Cassiopeia e da Távola Redonda. Ora, a propósito desta última revista, disse Óscar Lopes que nela "podem distinguir-se duas formas de reação" ao "realismo social": a do "verismo cético", "propenso aos matizes nauseados, sartrianos ou camusianos, do existencialismo", por um lado, e, por outro, a da "sensibilidade" a que pode dar-se "o nome inexato mas cómodo de «metafísica»" (LOPES, 1992, p. 1108). E se em Vário o "realismo" político ou o "verismo" quotidiano surgem (quase) sempre metaforicamente transmutados, a sua poesia acaba por representar também uma forma de compromisso entre estas duas tendências - a metafísica e a existencialista - emergentes ou dominantes nos anos em que vive em Portugal.

Assim, a assimilação das "novas teorias da expressão poética", que identifica com Eliot e Pound, e o conhecimento da "moderna filosofia europeia", que relaciona com o romance de língua francesa, são uma necessidade e um imperativo repetidamente declarados no "Texto 1" de Exodo. $\mathrm{E}$ ambos irão manifestar-se, de forma particularmente evidente, nos dois primeiros Exemplos, o Geral (1966) e o Relativo (1968).

A defesa de uma poética da complexidade, recorrente na crítica de Vário, insinua-se nos dois nomes privilegiados neste "Texto 1": Jorge de Sena e T. S. Eliot. Do primeiro, afirma-se que é o maior poeta português vivo. Do segundo, subscreve-se a ideia de que "a grande poesia necessita do estudo da grande prosa" (VÁRIO, 2000, p. 409)5 ; e transcreve-se, a encerrar o artigo, um parágrafo axial de "Tradição e Talento Individual”. A inquirição ontológica, a exposição reflexiva, a expressão barroca, a memória literária, a consciência e as responsabilidades históricas do escritor - são algumas das faces desses complexos poliedros poéticos de que falam Eliot, Sena e Vário.

Através da pena de T. Tio Tiofe, o autor dos Exemplos há de encontrar na poesia do patrício Osvaldo Alcântara, reunida em 1986, alguns traços precursores do labor poético que havia proposto à sua geração cabo-verdiana. Nessa altura, ela percorria os muito distintos caminhos do Suplemento Cultural (1958) ou de Seló (1962), herdeiros da fala chã de Jorge Barbosa e conducentes à intervenção socialista e panfletária dos anos da Independência. É por isso que, a propósito das "feições retóricas e barrocas" da poesia épica de Tiofe, resultantes da sua "exuberância verbal" ou "imagética", sugeriu José Vicente Lopes que elas terão causado especial estranheza "num país onde a poesia, em tese, tende a parcimoniosidade como a paisagem geral das ilhas” (LOPES, 1987, p. 29). Também José Luiz 
Tavares, autorretratando-se, virá a inscrever a sua "sintaxe escarpada" na orografia de Cabo Verde. Mas interessa agora fixar a passagem abrupta da simplicidade de um Jorge Barbosa para a complexidade dos Exemplos (de João Vário) e dos Livros de Notcha (atribuídos a Timóteo Tio Tiofe).

\section{AS EPÍSTOLAS DE TIMÓTEO TIO TIOFE}

No dia cinco de julho de 1976, data do primeiro aniversário da Independência de Cabo Verde, surge na página de Cultura do jornal Voz di Povo, coordenada por Arménio Vieira, um "Extrato da «Epístola ao meu irmão António a propósito de O Primeiro Livro de Notcha»", assinado por Timóteo Tio Tiofe. Nos parágrafos escolhidos por Vieira, o epistológrafo sustenta que, em Cabo Verde, "há mais livros bons de ficção do que de poesia". Já na conclusão do excerto selecionado, Vário-Tiofe reitera a necessidade de maior exigência na leitura crítica das obras literárias cabo-verdianas:

Só lendo, discutindo, exigindo o melhor do escritor cabo-verdiano, fomentando ou provocando o aparecimento em Cabo Verde de críticos literários lúcidos, cultos, profissionais, e de leitores interessados, exigentes, se pode esperar que uma literatura cabo-verdiana digna desse nome se forje e se imponha à consideração e ao respeito do mundo. (TIOFE, 1976, p. 19, cursivo do autor).

Numa nota que precede este extrato, Vieira explica o motivo da sua discordância relativamente à tese de Vário: "O autor, na sua avaliação, utiliza critérios estritamente formalistas e esteticistas, esquecendo que a literatura pode, e por vezes deve, assumir uma função utilitária de ordem política e social"; ora, foi justamente no campo da poesia, conclui Vieira, que a literatura de Cabo Verde "deu o seu contributo" à luta recente "pela emancipação política” (VIEIRA, 1976b, p. 19) - e este facto não deveria ser desprezado na avaliação das obras posteriores a Claridade (1936-1960).

Um segundo excerto desta epístola, intitulado "A propósito de $O$ Primeiro Livro de Notcha", é publicado em abril do ano seguinte. Na mesma página do Voz di Povo, Vieira apresenta uma "tradução literal" de "Le cancre”, de Jacques Prévert (de quem herdará a técnica do inventário, conforme hão de assinalar Pierrette e Gérard Chalendar). Os indícios da mudança do gosto literário por parte de Vieira reiteram-se na nota que (de novo) antepõe aos parágrafos de Vário: são estes, opina agora o poeta de Seló, "um relance" sobre a poesia cabo-verdiana "visando a superação de uma poética anquilosada pela repetição dos mesmos temas e a precisar de uma renovação ao nível da linguagem" (VIEIRA, 1977, p. 9). Desta vez, Vieira reprova apenas "o tom algo polémico e desabusado" de Vário.

Quando avalia as obras dos seus contemporâneos, envolvidos no movimento independentista da Nova Largada, o autor dos Livros de Notcha não sugere a necessidade de abandono dos motivos poéticos cabo-verdianos - e este é um dado muito importante. O que em rigor defende é 
a necessidade de criação de "uma linguagem poética nova na poesia cabo-verdiana”. Sobre este assunto, Vário-Tiofe antecipa o julgamento de Manuel Ferreira sobre o valor do mais apreciado poeta de Claridade:

[Não se] tem tentado uma verdadeira pesquisa ao nível da linguagem ou da matéria poetizável, uma salutar renovação da nossa poética como deve ser a preocupação fundamental ou a justificação da existência de cada nova geração de poetas. E a grande infelicidade para [os poetas da Nova Largada] reside no facto que tudo o que dizem, Jorge Barbosa o disse, muito antes deles, e melhor. (TIOFE, 1977, p. 9).

Mas há neste excerto da primeira epístola de Tiofe outros procedimentos importantes para a crítica cabo-verdiana coeva. Um deles tem que ver com a referência aos Cantos de Ezra Pound e ao Anabase de Saint-John Perse, poemas épicos modernos que, tal como O Primeiro Livro de Notcha, dispensaram a intervenção de personagens heroicas (segundo o modelo clássico); outro diz respeito à invocação de intelectuais conservadores, distantes portanto dos marxismos independentistas, e muito marcados, tal como Vário, pela experiência do exílio. Mas interessa sobretudo, e desde logo, assinalar a opção pela leitura crítica da poesia cabo-verdiana no quadro de um certo cânone ocidental e universal: agora as referências internacionais já não estão ao serviço da explicação localizada - como sucedia, na crítica cabo-verdiana, com os envios aos modernismos brasileiros ou ao neorrealismo português -, mas assumem a condição de modelos com os quais se deve confrontar a produção literária de Cabo Verde ${ }^{6}$.

Importa entretanto anotar alguns dos postulados propostos por T. Tio Tiofe, "investigador", na sua comunicação ao Congresso sobre as Literaturas Africanas de Língua Portuguesa realizado em Paris, em 1984. Muito à revelia das orientações críticas promovidas pelos organizadores desta reunião, o curto ensaio "Arte poética e artefactos poéticos em Cabo Verde: reflexões sobre os últimos 50 anos da poesia cabo-verdiana”, vem anunciar a emergência de uma estética refratária à expressão ou, mais justamente, à definição da "identidade individual e nacional". Isto porque os novos poetas estão agora marcados pela "fome de escrutínio da sua condição irredutível ou metafísica - a inefável identidade” (TIOFE, 1989, p. 315). A segunda epístola de Tiofe, escrita em Luanda, em 1978, dava já conta da recente ultrapassagem da estética claridosa, "predominantemente objetiva, ligada ao concreto", e da emergência de uma nova fase poética, marcada por "um léxico abstrato" de "ressonâncias especulativas" (TIOFE, 2001, p. 161). Esta segunda "fase estética" da literatura cabo-verdiana consolida-se depois da Independência e é identificada, em 1984, com os nomes de Arménio Vieira ou de Jorge Carlos Fonseca - além do precursor Osvaldo Alcântara e dos não especificados "autores com volumes publicados há anos", dos quais se destacaria o próprio Vário.

A mais delicada e consequente asserção de Tiofe talvez seja aquela em que define a nova "fase estética" da lírica cabo-verdiana através da mesma propriedade que atribuíra a João Vário (e a certo Osvaldo Alcân- 
tara): trata-se de uma "poesia que nada tem que ver com os problemas específicos de Cabo Verde". Convirá cotejar este e os anteriores contextos da afirmação de Tiofe, que destacarei em cada citação. Assim, o primeiro caso dá-se em 1975, na nota que introduz O Primeiro Livro de Notcha:

Até agora tenho publicado em volumes, sob o pseudónimo de João Vário, uma poesia que nada tem que ver com os problemas especificos de Cabo Verde. Era natural que, homem destas terras, um dia me voltasse para os seus problemas, as suas aspirações, e que tentasse dizê-las em poesia. (idem, p. 13).

Já na “Primeira epístola ao meu irmão António", escrita em 1974, a poesia de Vário e, em parte, de Osvaldo Alcântara, distinguia-se, não exatamente dos "problemas específicos de Cabo Verde", mas da poesia que neste arquipélago se escrevia:

[A] poesia de João Vário não tem nada que ver com a poesia cabo-verdiana, mas há um poeta cabo-verdiano que possui aqui e ali na sua poesia um tom remotamente semelhante Osvaldo Alcântara. (ibidem, p. 142).

Por fim, em 1984, no Congresso de Paris, aquilo que era próprio de João Vário e de algum Osvaldo Alcântara passa a definir, de uma forma geral, a nova fase da poesia moderna de Cabo Verde:

O tom novo desta poesia que nada tem que ver com os problemas específicos de Cabo Verde, e já se ouvia em certas composições de O. Alcântara, é representado por autores com volumes publicados há anos, como por outros - Arménio Vieira, Pedro Gregório, [Jorge] Carlos Fonseca, Vera Duarte - revelados essencialmente por Voz di Povo (...) e pela revista Raízes. (TIOFE, 1989, p. 314-315).

A intenção próxima destas teses sobre uma "poesia que nada [tinha] que ver com os problemas específicos de Cabo Verde" poderia estar relacionada com a correção das perspetivas críticas realistas e nacionalistas subscritas pelos organizadores do Congresso de Paris e difundidas, em particular, nas lições de Manuel Ferreira. $O$ investigador português não estabelecera qualquer distinção entre as "novas gramáticas" da poesia, por um lado, e a "saga histórica" cabo-verdiana inscrita nas obras de T. T. Tiofe, Corsino Fortes ou Oswaldo Osório, por outro - e esse procedimento excluía João Vário não apenas do corpus da poesia nova mas também do sistema literário cabo-verdiano. Mas o reparo de Tiofe poderia conduzir a uma consequência improvável: são os próprios Livros de Notcha, atentos aos "problemas" e "aspirações" de Cabo Verde, que se veem assim excluídos desse corpus semanticamente não localizado que define a nova fase estética da poesia de Cabo Verde. O paradoxo agudiza-se quando se tem presente que Tiofe quis ser um dos fundadores desta fase estética emergente: lê-se na sua epístola sobre O Primeiro Livro de Notcha que esta obra "representa, antes de mais, uma tentativa de criar uma linguagem poética nova na poesia cabo-verdiana" (TIOFE, 2001, p. 132). 
A propósito da nota que abre o primeiro Notcha, observou Osvaldo Manuel Silvestre que ela acusa a assimilação subconsciente, por parte de Vário, da "circunstância histórica" em que surge esse livro e da respetiva "doutrina" dominante nos "estudos africanos", assente no neorrealismo nacionalista e na dicotomia entre a África e a Europa (SILVESTRE, 2008, p. 630-636). Outro postulado do mesmo comentário de Osvaldo Silvestre diz-nos que, se abandonarmos as leituras dicotómicas contestadas pelo Tiofe das epístolas, e cujo modelo se encontra em Russel G. Hamilton, deixa de ser possível sustentar o "corte epistemológico" entre as poéticas de Exemplos e de Notcha. Ora é esta hipótese fulcral que, quando transposta para o panorama atual, pode permitir, paralelamente, a ultrapassagem de certo impasse crítico, próprio do chamado Período Universalista. Já vimos como na primeira epístola de Tiofe se lamenta que em Cabo Verde não se houvesse tentado, até àquele momento e salvo raras exceções, "uma verdadeira pesquisa ao nível da linguagem ou da matéria poetizável" (TIOFE, 2001, p. 133). Mas é necessário discutir agora o valor alternativo da conjunção empregue por Tiofe nesta frase: contra a cisão que esse "ou” propõe ou sugere, dir-se-ia que é justamente no interior da pesquisa linguística que se transmuda ou converte a matéria poética dos Livros de Notcha como aliás sucede em Pão \& Fonema (1974), de Corsino Fortes, objeto da segunda epístola de Tiofe.

A defesa da não separação da "linguagem" e da "matéria" poéticas quer na criação quer na exegese do texto, ou a necessidade de observá-las enquanto composto resultante de sentidos mutuamente construídos, reitera-se, já no presente século, e de modo absolutamente eloquente, nos importantes comentários de José Luiz Tavares ao seu Paraíso Apagado por Um Trovão. A partir de Theodor W. Adorno, Tavares vem defender "o abandono de uma estética do tema em favor duma estética da expressão" (TAVARES, 2010, p. 301). E é justamente esta perspetiva teórica - raramente acolhida pela crítica da poesia africana escrita em português - que permite superar as aporias da localização de Vário e de Tiofe no sistema literário cabo-verdiano.

\section{ARMÉNIO VIEIRA, LEITOR DE JOÃO VÁRIO}

A 23 de janeiro de 1976, na secção cultural do jornal Voz di Povo, surge um excerto inédito do "Canto Segundo" do futuro Exemplo Próprio (1980). Acompanha-o um comentário de Arménio Vieira muito certeiro no apuramento dos traços fundamentais da poesia de Vário. Escreve o jornalista cultural, nesta primeira nótula crítica, que "a meditação filosófica é o cerne da poesia de Vário"; acrescenta depois, quanto ao plano da expressão, que estamos perante "um poeta barroco", cujo discurso se torna "por vezes hermético e dificilmente inteligível”. Estes tópicos da expressão barroca, da reflexão ontológica e da inteligibilidade dos seus sentidos definem a crítica da poesia do autor dos Exemplos, desde Arnaldo França (1993) até 
Silvina Rodrigues Lopes (2007 e 2009). Num tempo em que o primado da forma ou do conteúdo competiam na arena crítica cabo-verdiana, Vieira parece assumir a irredutibilidade dos sentidos do texto poético a qualquer discurso filosófico, quer dizer, racional, sistemático e transitivo. Mas se "no poeta Vário estes dois aspetos" - o artístico e o filosófico - "se apresentam de forma coesa, difícil de separar", o redator do Voz di Povo atribui diferentes valores a cada um deles:

A textura poética, o nível da sua elaboração como linguagem artística, é por vezes deveras notável. Todavia, não temos dúvidas em afirmar que toda essa construção cai um pouco por terra quando posta em confronto com o seu suporte filosófico, de cariz metafísico, idealista até ao solipsismo, o que dá ao discurso de Vário uma feição por vezes irrealista. (VIEIRA, 1976a, p. 6).

Os versos que, na leitura de Vieira, confirmam a inscrição de Exemplo Próprio na metafísica e no idealismo filosóficos são estes: "Ah, homem, deixa a tua porta abrir-se/ sobre a insatisfação: que podes tu/ modelar de mais precioso que o teu espírito?” (VÁRIO, 2000, p. 167)7. Vieira não reconhece aqui as questões identitárias e de cidadania tratadas em Exemplo Próprio - que, aliás, ainda não teria lido na totalidade. O seu comentário tem que ver com as dificuldades de interpretação desta poesia e com a consequente resistência à sua aceitação por parte do público leitor de Cabo Verde. É neste âmbito que intervém a defesa de uma filosofia materialista que, atenta ao "campo político, económico e social", nele encontra o espaço da ação e da luta capazes de promover a elevação cultural e espiritual do povo cabo-verdiano. Contra certa aceitação resignada e ensimesmada do isolamento do poeta face a esse público (ainda) incapaz de recebê-lo, Vieira advoga a revolução cultural que, em um tempo futuro, e sem exceções elitistas, faça de cada cabo-verdiano um potencial apreciador da mais erudita, barroca e metafísica expressão poética.

A reserva levantada por Vieira não significa, portanto, que a poesia de Vário não deva "ser lida e bem ponderada"; pelo contrário, ela "merece um esforço de leitura e compreensão". Só assim se poderá distinguir o que há de mais válido nas "múltiplas sugestões que tal poesia encerra". É esse exercício, justamente, que Vieira ensaia em 1978, a partir dos dois fragmentos do Segundo Livro de Notcha publicados no Voz di Povo. Em nova nota introdutória, condena-se a "preguiça mental" de quem se recusa a "difícil tarefa" de "esclarecer quanto possa estar oculto" sob os "símbolos" e os "significantes poéticos" de que o poeta lança mão. Perante as dificuldades, o leitor de Vário - como o da melhor poesia moderna - deve recorrer, "sempre que necessário e possível, à ajuda de fontes de consulta". Esta perceção das dificuldades contingentes dos Exemplos, na terminologia de George Steiner, encontra exemplo num oblíquo envio a Moisés: "E ninguém os tirou das águas/ ou os apanhou de entre os juncos e os sinais" (TIOFE, 2001 , p. 273). Vieira não propõe, contudo, qualquer implicação de senti- 
dos resultantes da referência ao legislador hebraico e às comuns narrativas, em que se inscreve este relato bíblico, das crianças prodigiosas, e por isso perseguidas e ameaçadas - como Ciro ou Édipo, conforme recorda H. D. F. Kitto - e entre as quais Vário parece encenar a sua própria biografia (em especial no longo testemunho que oferece, por escrito, a Michel Laban). Neste momento, o propósito de Vieira é apenas o de assegurar a seguinte ilação: "Vário - urge reconhecê-lo - tem dado contributo válido para a dignificação da poesia em Cabo Verde" (VIEIRA, 1978a, p. 6).

A progressiva aproximação de Vieira às teses expendidas nas epístolas de Tiofe não decorreu, porém, sem as hesitações e as ressalvas próprias de um tempo de grandes transformações políticas e de acesas polémicas culturais, artísticas e literárias. Caracterizam esse tempo, em particular, o "regime de Partido Único socializante" e as suas prolongadas discussões “sobre a «poesia para o povo» e a «poesia para a elite», polémicas essas demonstrativas da dominância de preconceitos populistas e mistificadores, próximos do «realismo socialista» jdanovista", conforme recorda J. L. Hopffer C. Almada (1998, p. 150). O Arménio Vieira do suplemento Ariópe ou do poema "Plano, reconstrução, aventura", por exemplo, esteve próximo desta doutrina que destinava à expressão artística uma função política imediata e pragmática - e a que correspondia, necessariamente, a defesa de uma linguagem acessível às massas alfabetizadas mas carentes de educação e cultura literárias.

Vieira mantém um interesse histórico e político pelos "artefactos poéticos" de imediata intervenção política que não se acha no ensaísmo de Vário-Tiofe - mesmo quando, no advento da Independência Nacional, o propósito e as práticas de rutura formal fazem a sua aparição nas obras de um Corsino Fortes ou de um Oswaldo Osório. No seu comentário à primeira epístola de Tiofe, Vieira contesta, como vimos, a proposição segundo a qual, em Cabo Verde, a prosa de ficção vinha sendo superior à poesia, já que ela decorria de "critérios estritamente formalistas e esteticistas". A acusação repete-se, dois anos depois, no "breve comentário" à conferência de João Vário sobre "As estruturas da lírica africana contemporânea", realizada na cidade da Praia. Também nesta ocasião, diz Vieira, o preletor "não se preocupou muito em compreender a poesia engajada ou de temática ideológica". Todo o seu comentário à lição de Vário é, aliás, bastante depreciativo: o conferencista teria sido incapaz de escudar a defesa da superioridade do seu cânone pessoal (Perse, Eliot, Pound e Quasimodo) num conjunto mínimo de argumentos válidos; ao afirmar que "o sentido não é um elemento essencial à poesia", Vário teria lançado apenas mais "uma justificação para os seus próprios exercícios poéticos" (escopo que, esquecido o tema pré-definido, dominaria afinal toda a conferência); a informação teórico-literária de Vário teria sido colhida na "poética estrutural" coeva; e a "condição humana" ali inquirida seria apenas um título de André Malraux (VIEIRA, 1978b, p. 6). Acrescente-se ainda que, ao contrário de Vário, Vieira não se mostrava então receptivo a entender a Bíblia como literatura. 
Entretanto, podemos extrair outro princípio destes comentários. O poeta que exerce também a crítica literária, como acontece com Vário e com Vieira, deve distinguir as suas escolhas pessoais, enquanto criador, dos seus juízos sobre as produções alheias, enquanto crítico ou historiador da literatura; este, ao contrário daquele, tem o dever de considerar - se necessário recorrendo a critérios não estéticos - o valor de determinadas poéticas com as quais, enquanto autor, não precisa de se identificar. Significa isto, no caso vertente, que a "grande cruz vermelha" que Vieira irá traçar sobre os seus "poemas transitivos" não pretende rasurar a pretérita poesia panfletária de intervenção social e política; no seu contexto e alcance muito próprios, ela cumpriu uma função importante na história recente das ilhas de Cabo Verde.

Mais consentânea com as convicções de Vário, e conforme testemunham os Livros de Notcha, é a possibilidade do compromisso entre o labor linguístico e estético, por um lado, e a intervenção político-social, por outro. O melhor exemplo moderno desta confluência, Vladimir Maiakovski, seria, aliás, recordado por Vieira, que traduz (a partir do francês) e publica (no Voz di Povo) um poema do modernista russo. Assim, a primeira epístola de Tiofe enaltece as aptidões (mais do que as realizações...) de Ovídio Martins e, com particular desvelo, o Osvaldo Alcântara do "Romanceiro de São Tomé”, ciclo de poemas elogiado também, em 1984, na comunicação ao Colóquio de Paris. Os dois Livros de Notcha, escritos com o propósito assumido de contribuir para uma renovação da poesia cabo-verdiana, inscrevem-se justamente neste desígnio: homenagear e perpetuar o exemplo dos heróis possíveis, populares e patrícios, fazendo uso de uma linguagem tão elevada quanto a matéria narrada no poema.

Já o pleno acordo entre as intervenções críticas dos dois poetas há de surgir, entretanto, a propósito da necessária “superação de uma poética anquilosada pela repetição dos mesmos temas e a precisar de uma renovação ao nível da linguagem", conforme escreve Vieira na nota ao excerto da primeira epístola de Tiofe. Mais tarde, em junho de 1978, durando ainda "o antigo debate sobre o conteúdo e a forma” do poema, o coordenador cultural do Voz di Povo reforça o mesmo apelo aos (agora muito menos ativos) poetas do seu país: as produções futuras devem assegurar a "diversidade da forma e dos temas" - conforme o "gosto", o "talento" e "a preparação de cada poeta" (VIEIRA, 1978c, p. 6). Este preceito, que começava a ser praticado também nas páginas da revista Raízes, surge reiterado na recensão crítica de Vieira ao livro O Cântico do Habitante precedido de Duas Gestas (1977), de Oswaldo Osório. Cotejando esta obra com o inaugural Caboverdeamadamente Construção Meu Amor (1975), o recenseador considera que, "sob um ponto de vista estritamente formal", o primeiro livro fora superior a esta nova coletânea: a composição "mais cuidada", "ambiciosa” e inovadora e a maior "qualidade e pesquisa vocabulares" haviam-lhe garantido essa distinção. O Cântico do Habitante tinha, porém, a seu favor, "uma novidade de outra ordem": 
a de ser um texto virado para temas que ultrapassam o panorama nativo do seu autor, visando problemas de natureza universal ou universalista, facto de certo modo raro adentro da poesia cabo-verdiana, eivada de um cunho e de uma temática regionalistas que vêm dos tempos da Claridade. (VIEIRA, 1978c, p. 6).

Porque não privilegia nem despreza qualquer desses aspectos, a recensão de Vieira parece superar o referido "antigo debate entre o conteúdo e a forma” do poema; mantém-se, no entanto, a observação isolada ou não concatenada dos repertórios temáticos e das estratégias expressivas presentes no texto poético. Assim, a citação destacada inscreve-se nesse procedimento crítico, hoje muito atuante entre os ensaístas cabo-verdianos, que concentra em um certo entendimento do universalismo temático e da expressão metafórica os mais ativos critérios da avaliação da produção poética atual. Será preciso esperar pela metapoesia e pelos paratextos de José Luiz Tavares para vermos perturbado este tipo de descrição e de valoração da poesia recente em Cabo Verde.

\section{A CRIAÇÃO DE SILVENIUS}

Se o 8 de março de 1914 assinala o dia triunfal da vida de Fernando Pessoa, conforme a ficção autobiográfica endereçada a Adolfo Casais Monteiro, o 23 de janeiro de 1976 assinala o dia triunfal da vida de Arménio Vieira. Um poema sem título, epigrafado pelo mito de Medusa, iniciado pelo verso "Quem acordado e com os seus sentidos iluminados de frente”, é publicado neste dia no jornal Voz di Povo - exatamente na mesma página, já aqui revisitada, em que surge um excerto do Exemplo Próprio de Vário comentado por Vieira. A autoria deste poema é atribuída a Silvenius, um nome até então desconhecido dos anais poéticos cabo-verdianos.

O olhar da Medusa
persegue o bailarino.
Quem não for subtil
petrifica-se.

Quem acordado com os seus sentidos iluminados de frente por enormes arcos voltaicos

e depois de tudo ponderar com padrões corretos

e tara certa

pode tolerar em sua cabeça

o nojo destes trapos e a sua caligrafia sem almas?

A pavorosa nomeação de um poema arcaicamente útil

a começar do primeiro verso legível e ortográfico

passando pelos seus intestinos carcomidos de salitre

até aos gemidos com que acaba

torpemente e amarelos.

Versos, letras, dejetos

rótulos de registo e cartaz. 
Até à invenção de outros e o modo da sua inscrição em símbolos de alfabeto novo, hieróglifos inominados caligramas, signos fechados e selados em ânfora de barro ao mar atirada para o regalo de prováveis peixes-martelos seláceos anónimos, teleósteos virgens percutindo o barro como um tambor de festa. Algas, moluscos, limos, grinaldas, signos e fitas coloridas para um festival de peixes. (SILVENIUS, 1976, p. 6).

Na referida carta sobre a génese dos seus heterónimos, conta Fernando Pessoa que, logo após a redação de "O Guardador de Rebanhos", regressaria a si mesmo, enquanto ortónimo, através de "Chuva oblíqua" - um poema em que confluem todos os planos espácio-temporais de um sujeito poético liberto em duplo. Se quiséssemos perseguir a analogia entre as invenções de Caeiro e de Silvenius, a expressão extraída do poema intersecionista encontraria paralelo na locução "até à invenção de outros" neste caso, de outros alfabetos, hieróglifos, caligramas; o mesmo será dizer: de outro(s) poeta(s).

No percurso da poesia de Vieira, este primeiro texto de Silvenius tem a montante o "Itinerário de um viajante metafísico", nunca recolhido em livro, e a jusante o "Prefácio a um livro futuro", incluído no inaugural Poemas (1981). Com o primeiro, ele partilha a narrativa da queda de um antigo mito causada por uma espécie de epifania da experiência ou da razão. As entidades metafísicas do "Itinerário..." correspondem, em Silvenius, à ilusão da função social da poesia. Como os deuses e os demónios foram derrubados pela experiência e pela compreensão da realidade humana, assim a poesia utilitária, legível e ortográfica, será negada pela razão sensorial, tecnológica e ética - ou seja, pela razão própria do poeta "acordado", de "sentidos iluminados" por "arcos-voltaicos", e que tudo avalia "com padrões corretos/ e tara certa". Do "Itinerário..." até Silvenius, as diferentes instâncias da comunicação poética sofrem transformações importantes: o sujeito da enunciação, que se convertera ao materialismo, ingressa no idealismo solipsista; o discurso poemático repudia o pragmatismo e torna-se metafórico; enfim, depois de "queimado o endereço" (cf. "Setembro dói e sangra"), a "mensagem que se comunica[va] de homem para homem" fecha-se e sela-se "em ânfora de barro ao mar atirada" - e aos seus improváveis habitantes-recetores.

Quanto ao "Prefácio a um livro futuro", registe-se o modo como ele reelabora a posteriori a rutura ou a transição estética ocorrida na obra de Vieira. Assim, a origem de Silvenius surge sincrónica e historicamente situada nos meses de dezembro e de janeiro, fazendo coincidir o calendário biográfico com o simbolismo genésico do solstício de inverno. Os dois meses que marcam a transição do velho para o novo transportam um léxico muito semelhante. Em 1976, no jornal Voz di Povo, dezembro é o mês da "caligrafia" e do "poema arcaicamente útil", do "nojo" dos seus "trapos", do "poema (...) útil" de "verso legível e ortográfico"; em 1981, no livro Poe- 
mas, dezembro é o mês da "ortografia/ da velha poesia utilitária", da "nojenta gastronomia poética", dos "versos úteis" dos "poemas transitivos" e dos “ortopoemas". Em 1976, no Voz di Povo, janeiro é o mês da "inscrição/ em símbolos de alfabeto novo" e da "invenção de outros" nomes; em 1981, em Poemas, janeiro é o mês da disposição das "letras do alfabeto/ em sentido oposto" e dessa "espécie de suicídio" do poeta 'Arménio Vieira'.

O poema com que Vieira procura fugir à perseguição da Medusa do Partido Único e do seu olhar petrificante foi improvisado nas instalações do jornal Voz di Povo; o pseudónimo Silvenius respondeu ao desejo circunstancial de ocultar o ortónimo que assinava o (já referido) comentário a um fragmento de João Vário ${ }^{8}$. Recorde-se que, na sua anotação, Vieira reconhecera que a "textura poética” daqueles versos, o nível "deveras notável” da sua "elaboração como linguagem artística”, mereciam "um esforço de leitura e compreensão" (VIEIRA, 1976a, p. 6); mas as "múltiplas sugestões" que tal poesia guardava, no seu discurso "hermético e dificilmente inteligível", só poderiam ser desveladas por um leitor de "espírito modelado" por uma sociedade económica, política e culturalmente mais evoluída do que o Cabo Verde coevo. Ora, o primeiro Silvenius é a catarse anarquista destas afirmações comprometidas com o demorado projeto de reconstrução nacional; parafraseando Césaire e Rimbaud, dir-se-ia que este nome vinha postular, com irritação e impaciência, uma poesia dirigida ao culto da liberdade livre.

Mais do que as tonalidades vocabulares dos Exemplos que por ali talvez ecoem ("depois de tudo ponderar com padrões corretos/ e tara certa”), é a reformulação enquanto ars poetica das observações críticas acerca de Exemplo Próprio que faz da intervenção de Vário na cena crítica e artística contemporânea a condição necessária e suficiente para o advento de Silvenius. Apesar disso, deve reconhecer-se que, na sua realização futura, é o ortónimo Arménio Vieira, se comparado com Silvenius, quem mais recebe do espólio de Vário9. Ao pseudónimo Silvenius serão reservados, nesta primeira fase, os versos da circunstância em que se despede dos companheiros de redação do Voz di Povo. E isto significa que o "hermetismo" discutido na anotação de Vieira e advogado no poema de Silvenius, os "hieróglifos" em que deveria exprimir-se o eleito do sol, os "signos fechados e selados" como no Apocalipse de João, os "caligramas" reinventados desde Apollinaire, quer dizer, as regras da ars poetica enunciadas neste poema são menos os propósitos de um manifesto programático, que implicaria o sacrifício do nome 'Arménio Vieira', do que a negação dos artefactos poéticos, isto é, dos estafados "rótulos de panfleto e cartaz" que, por aqueles anos, celebravam a política do PAIGC e a Independência de Cabo Verde.

\section{REFERÊNCIAS BIBLIOGRÁFICAS}

ALMADA, José Luís Hopffer C. A poética cabo-verdiana pós-Claridade - Alguns traços essenciais da sua arquitetura. In: VEIGA, Manuel. Cabo Verde - Insularidade e Literatura. Paris: Karthala, 1998, p. 137-165. 
BELO, Ruy. Obra Poética de Ruy Belo - Volume 3. Lisboa: Editorial Presença, 1984.

LOPES, José Vicente. Novas estruturas poéticas e temáticas da poesia cabo-verdiana (conclusão). In: Ponto \& Vírgula. Mindelo, n. ${ }^{\circ}$ 17, p. 24-33, dez. 1987.

LOPES, Óscar e SARAIVA, António José. História da Literatura Portuguesa. 16a ed. Porto: Porto Editora, 1992. [Capítulo citado, "Época Contemporânea”, redigido por Óscar Lopes].

RODRIGUES, Ana Salgueiro. O mito da Macaronésia na ficção de G. T. Didial. In: Vozes de Cabo Verde e de Angola: Quatro Percursos Literários. Lisboa: CLCLE -FLUL, 2010, p. 109-163.

SILVENIUS. [Arménio Vieira]. Quem acordado com os seus sentidos iluminados de frente [poema]. In: Voz di Povo. Praia, p. 19-23 jan. 1976.

SILVESTRE, Osvaldo Manuel. João Vário: Todo o Homem é Babel. In: ALMADA,José Luís Hopffer C. (coord.). O Ano Mágico de 2006 - Olhares Retrospetivos sobre a História e a Cultura Cabo-Verdianas. Praia: Ministério da Cultura de Cabo Verde, 2008, p. 627-660.

SILVESTRE, Osvaldo Manuel. Apresentação de um poeta errante. In: VÁRIO, João. Exemplos. Lisboa: Tinta-da-china, 2013, p. 287-303.

TAVARES, José Luiz. Paraíso Apagado por Um Trovão. $3^{a}$ ed. Assomada: US Edições, 2010.

TIOFE, Timóteo Tio. Extrato da "Epístola ao meu irmão António a propósito de O Primeiro Livro de Notcha”. In: Voz di Povo. Praia, n. ${ }^{\circ} 48$, p. 19-5 jul. 1976.

. A propósito de O Primeiro Livro de Notcha. In: Voz di Povo. Praia, n. ${ }^{\circ}$ 91, p. 9-29 abr. 1977.

. Arte poética e artefactos poéticos em Cabo Verde - Reflexões sobre os últimos 50 anos da poesia cabo-verdiana. In: Les Littératures Africaines de Langue Portugaise: A la Recherche de L'identité Individuelle e Nationale. Paris: FCG, 1989, p. 309-315.

. O Primeiro e o Segundo Livros de Notcha. Mindelo: Edições Pequena Tiragem, 2001.

VARELA, João Manuel. Encontro com João Varela/João Vário/Tio Tiofe/G. T. Didial. In: LABAN, Michel. Cabo Verde - Encontro com Escritores, vol. II. Porto: Fundação Eng. António de Almeida, 1992, p. 451-473.

. Carta aos editores de Êxodo. In: Anais. Mindelo: Academia de Estudos de Culturas Comparadas, vol. 2, n. ${ }^{\circ}$ 1, p. 125-135, abr. 2000.

VÁRIO, João. Texto 1. In: Exxodo. N. ${ }^{\circ}$ 1. Coimbra: Livraria Almedina, 1961, p. 1-3. 
2000.

VIEIRA, Arménio. Comentário a "Fragmento de Exemplo Próprio (inédito)”. In: Voz di Povo. Praia, n. 26, 23 jan. 1976a.

. Nota a Extrato da «Epístola ao meu irmão António a propósito de O Primeiro Livro de Notcha». In: Voz di Povo. Praia, n. ${ }^{\circ} 48,5$ jul. 1976b.

. Nota a "A propósito de O Primeiro Livro de Notcha". In: Voz di Povo. Praia, n. 9 91, p. 9, 29 abr. 1977.

. Nota introdutória de Arménio Vieira a "2 fragmentos de $O$ Primeiro Livro de Notcha”. In: Voz di Povo. Praia, n. ${ }^{\circ} 129$, p. 6, 28 jan. 1978a.

. Breve comentário à conferência de João Vário "As estruturas da lírica africana contemporânea”. In: Voz di Povo. Praia, n. ${ }^{\circ} 131$, p. 6, 13 fev. 1978b.

. "Prato forte desta página..." [Nota sem título]. In: Voz di Povo. Praia, n. ${ }^{\circ}$ 149, p. 6, 17 jun. 1978 c.

. O Eleito do Sol. 2a ed. Lisboa: Vega, 1992a.

. "Encontro com Arménio Vieira”. In: LABAN, Michel. Cabo

Verde - Encontro com Escritores, vol. II. Porto: Fundação Eng. António de Almeida, 1992, p. 501-534.

Recebido para publicação em 31/05/2015

Aprovado em 22/08/2015

\section{NOTAS}

* Doutorado em Literatura de Língua Portuguesa pela Universidade de Coimbra com uma tese sobre João Vário, Arménio Vieira e José Luiz Tavares. Membro integrado do Centro de Literatura Portuguesa da Universidade de Coimbra e membro colaborador do Centro de Investigação em Estudos Regionais e Locais da Universidade da Ilha da Madeira (UMa). Professor de Português e de Literatura Portuguesa no ensino básico e secundário.

2 Destes factos deu também conta Ana Salgueiro Rodrigues, que escreve: "Ainda que o texto publicado em 1961 coloque Varela no contexto do sistema literário português, do qual, com o seu exílio europeu (...) e com a independência cabo-verdiana, o autor inequivocamente se distancia, ele apresenta, desde logo, o perfil do projeto literário que manterá até ao final da sua vida" (RODRIGUES, 2010, p. 112).

3 Um indício revelador da comunhão com estes dois poetas portugueses encontra-se num depoimento de Ruy Belo sobre o autor de Fidelidade: "E João Vário - onde andará ele? - e os moços da revista Exxodo, falavam de Jorge de Sena como de um mestre. Que posso eu dizer?" (BELO, 1984, p. 466).

4 Esta consciência e defesa da condição cosmopolita da literatura estará igualmente presente na sua análise do sistema cabo-verdiano: no "período atual", diz Tiofe em 1984, "não se trata já de poetas de Cabo Verde que escrevem poesia cabo-verdiana, mas de poetas de Cabo Verde que escrevem poesia" (TIOFE, 1989, p. 315). 
5 Cito a defesa do estudo da prosa que, em raro registo chistoso, se lê no Canto Segundo de Exemplo Coevo: "como diz o Reverendo Padre Eliot,/ a grande poesia necessita do estudo da grande prosa" (VÁRIO, 2000, p. 409). A afirmação de Eliot encontra-se em The Use of Poetry.

6 A publicação integral da "Primeira epístola ao meu irmão António" dá-se apenas em 1979, na revista África, dirigida por Manuel Ferreira. São então tornados públicos os momentos da missiva que reiteram a necessidade de uma crítica literária exigente; e que reafirmam o valor ainda não superado dos primeiros claridosos. Mas não se trata agora de substituir o realismo contemplativo pelo realismo socialista, como nas "Breves notas sobre a literatura cabo-verdiana" (1948), nem de fazer suceder à "saga quotidiana" a "saga histórica", como no volume Literaturas Africanas de Expressão Portuguesa I (1977). O que Tiofe propõe, diferentemente de M. Ferreira, é a criação de uma poesia que transponha os "quadros limitados da vida física, tradicional, do seu país" e que compreenda não só um lastro cosmopolita de referências culturais mas também essa dimensão metafísica ou ontológica "a que todo o homem de uma certa cultura ou dotado de uma certa estrutura «reflexiva» não escapa” (TIOFE, 2001, p. 136).

7 O poema reage ao problema formulado aventando esta hipótese: “Os bens da tua vida são talvez esse caos,/ melhor e mais que a morte/ mais e melhor que a perenidade" (VÁRIO, 2000, p. 167). Alheio à enumeração anafórica e celebrativa com que encerra o mesmo "Canto Segundo" de Exemplo Próprio, Vieira parece identificar o caos destes versos com os problemas sociais do seu tempo, por certo não apenas cabo-verdianos; por isso afirma que urge reconhecer tal caos - e "pugnar pela sua organização"... (VIEIRA, 1976a, p. 6).

8 Quando narra estes factos a Michel Laban (VIEIRA, 1992b, p. 526), Vieira prefere calar as razões que o levaram a optar por um pseudónimo. Os poemas que virá a dedicar "aos ex-companheiros do jornal Voz di Povo" são contudo esclarecedores quanto àquilo que fica para a história da literatura de Cabo Verde. Recorde-se, a este propósito, que o protagonista de $O$ Eleito do Sol, primeiro romance de Arménio Vieira, ficou "proibido de revelar o seu nome" por delito de discordância com o Ministro da Educação de quem era subordinado (VIEIRA, 1992a, p. 90).

9 Vejam-se, por exemplo, os postulados e o léxico da reflexão filosófica ensaiada na secção “Poesia dois - 1974-1979”, incluída em Poemas (1981), e, em particular, o poema "Canto do crepúsculo (fragmentos)", uma evidente glosa aos Exemplos de João Vário. 